\title{
Implementation of Outdoor Games to Improve 4-5 Year Old Children's Number Sense
}

\author{
Fitri Nurhayati ${ }^{1 凶}$ Harun Rasyid $^{2}$ \\ Pasca Sarjana Universitas Negeri Yogyakarta, Indonesia
}

\begin{abstract}
This research implemented some outdoor games, which can improve students' number sense, through a quasi-experiment project with one group pretest-posttest design in a kindergarten class (4-5 years old) in Bantul district. The students were invited to participate actively in outdoor games. They can contribute directly to the outdoor games which can develop their competence in number using learner-centred method and supported by the teachers. The right outdoor games can be identified as a way to improve students' sense in numbers. Many teachers can also shift their perspectives from the old class management they had.
\end{abstract}

Keywords: outdoor games, number sense, 4-5-year-old children

\begin{abstract}
Abstrak
Penelitian ini mengimplementasikan beberapa permainan di luar ruangan, yang dapat meningkatkan kemampuan mengenal angka pada anak melalui penelitian quasi-eksperimen dengan satu kelompok desain pretest-posttest pada kelompok A taman kanak-kanak (4-5 tahun) di kabupaten Bantul. Dalam penelitian ini anak-anak diminta untuk berpartisipasi aktif dalam permainan luar ruangan (outdoor). Dengan adanya permainan luar ruangan (outdoor) mereka dapat berkontribusi langsung dalam permainan yang dapat mengembangkan kemampuan mengenal angka karena menggunakan metode berpusat pada peserta didik dan didukung oleh para guru. Permainan luar ruangan yang tepat dapat diidentifikasi sebagai cara untuk meningkatkan kemampuan anak dalam mengenal angka. Selain itu, guru juga dapat mengalihkan perspektif mereka dari manajemen kelas klasikal yang selama ini mereka terapkan pada anak.
\end{abstract}

Kata kunci: permainan luar ruangan (outdoor), pengenalan angka, anak usia 4-5 tahun

@ Jurnal Obsesi Prodi PG-PAUD FIP UPTT 2019

$\triangle$ Corresponding author :

Address : Yogyakarta, Indonesia

Email : fitrinurhayati.2017@student.uny.ac.id
ISSN 2356-1327 (Media Cetak)

ISSN 2549-8959 (MediaOnline) 


\section{INTRODUCTION}

In the recent years, children have more interest in Mathematics activities than the previous years. This is supported by a research (Nilsson, Sollervall, \& Milrad, 2009) showing that the interest of children in Sweden toward Mathematics activities activity increased recently, so it needs more attention. Another research (Misfeldt \& Zacho, 2016) conducted in Denmark demonstrates that the Mathematics act'vities's increased along with the changing era and technologies which become more sophisticated. Learning Mathematics in pre-school must be different from Elementary school, especially the degree of the content. National Council of Teachers of Mathematics (NCTM) (Dunphy et al., 2014) states that the materials of Mathematics for children included the introduction of number, geometry, measurement, algebra, and data presentation. From all contents, it cannot be denied that all of them are related to children's daily life and can be found around them. One of the Mathematics activities needed to be developed in children is the introduction of numbers. The competence of students to recognize number is important since it is related to their daily activities (Lestari KW, 2011).

The experience of children to sense numbers in the early childhood can help them to develop their Mathematics competence in the next years. It means that children who learn numbers in the early childhood have more possibilities to be capable in Mathematics and to be involved in their daily activities (Fitria, 2013). It may have an effect to children's life if numbers are not introduced in the early childhood. Seeing the importance of recognizing numbers for life skill in the future, parents and teachers need to teach and introduce numbers to improve their life skills and development. The ability to recognize numbers belongs to cognitive development aspect which becomes basic for children's intelligence development. Intelligence is a continuous process resulting in structure needed in the interaction and environment (Daryati, 2011). Realizing the importance of cognitive development aspect in early childhood, which includes counting, therefore, the activity of counting or introducing numbers should be done in early childhood (Nurmalina, 2016). According to Mutiah (2010: 162), the benefit of numbers is to stimulate children awareness towards numbers, thus if the numbers were learned as a part of daily routines, the children will get used to Mathematical calculation when they play games. To develop this competence, children need to be provided by some experiences they build on their own through exciting activities. Thus, the competence of children in recognizing numbers will develop well.

As numbers are really important in people's daily activities, introducing numbers has been started since early childhood. The teaching and learning of numbers is hierarchical, which means the introduction of numbers done in early childhood needs to be done through stages. It has been decided on Achievement Standard of Early Chilhood Development (STPPA) in early childhood 2013 curriculum. It can be seen from STPPA that the ability to recognize numbers starts at year of 3-4, indicated by the ability of mentioning numbers using fingers. As they grow, the activity to introduce numbers also increases. Mentioned in STPPA, the indicator of introducing numbers at year of 4-5 is recognizing numbers (symbol) or number sense. Thus, numbers should be introduced in Kindergarten at year of 4-5 
(class A). It is said as early concept simulation of numbers (Nurmainis, 2012).

Based on previous study conducted in the early of July 2018, through observation and interview in ten schools in Bantul district, children at the age of $4-5$ still have difficulty to recognize number. For example, they cannot differentiate between " 6 " and "9". Besides, when children try to match things with their number, they still need the help from the teacher. This occurred since they lack experience. They only completed worksheet in the classroom. From that study, development on methods and strategies is needed, particularly in introducing numbers to early childhood (45 years old) in order to make them achieve the standard of development. In particular, he (Nilsson et al., 2009) analysed how children learn number through their daily activities done outside (outdoor). Nah \& Lee, (2016) also conducted a research to see children's participation outside classroom through certain methods and development. From the researches, it can be inferred that outdoor games offer more chances for children to explore their own knowledge, offer learner-centered learning, and offer children's active involvement in learning numbers. In outdoor class, children have various choices about what and how to play They also can try every activitiy presented by the teacher. The need of playing plays important role for children development. Environment and adult, in this case parents or teachers, need to facilitate the need of children by providing many games supporting children development. Of course, the games and the instruments may not be expensive, even anything as long as it is useful for playing (Pradana, 2016). When children are playing, they get freedom. They result in making own decision about what they are learning in the real situation (Hinkley,
Brown, Carson, \& Teychenne, 2018). Thus, this research aims at finding out how the implementation of outdoor games is to improve number sense of 4-5-year-old students.

\section{METHODOLOGY}

This research used one group pretest and posttest design, in which a pretest is given in the beginning of the treatment and a posttest after the treatment. By using this design, the accuracy can be achieved since the result before and after the treatment can be compared (Sugiyono, 2017:74). The design can be seen as follows.

\section{$\mathrm{O}_{1} \mathrm{X} \mathrm{O}_{2}$}

Info:

$\mathrm{O} 1=$ pretest value (before treatment)

$\mathrm{O} 2=$ posttest value (after treatment)

This research was employed through a collaboration with two kindergarten teachers. Outdoor games were selected based on the previous study stated that children are lack of direct experience when they learn in indoor classroom. Outdoor games were accomplished through a collaboration between teachers, students, and the researcher. Outdoor games selected for this research consisted of two games namely bowling number games and modified matching it games.

The subjects in this research were a class of kindergarten A students (4-5 years old) with 15 children and two teachers in Bantul district. Teachers involved in this research have 9-year-experiences of teaching. Teachers have the role to guide the outdoor games and fill the assessment form provided. Children at the age of $4-5$ years old were selected as these ages were the early school age and they still have difficulties in learning number. 
The selection of kindergarten was based on certain criteria, 1) the minimum size of the yard which should be 6X6 meters. By having a large yard, children will feel free to move and do the outdoor games designed. 2) The yard is surrounded by fences to make the outdoor games safe for the children. 3) The availability of water outside the classroom is considered since the children need to wash their hands after the games

Observation and test were used as the techniques of collecting data for this study. Observation aimed at finding out the improvement before and after the treatment. The instrument for observation was in the form of checklist. In the end of the lesson, a test was employed through worksheet focusing on numbers recognition. The worksheet became the documentation which can be used as evaluation materials towards children's development in learning numbers. The instruments to gather data were in the form of observation sheet (check list) and test (worksheet). The instruments were presented as follows.

Table 1. Blueprint of number sense on group A students

\begin{tabular}{|c|c|c|}
\hline Indicators & Description & Instrument \\
\hline $\begin{array}{l}\text { Counting 1- } \\
10\end{array}$ & $\begin{array}{l}\text { children are } \\
\text { able to count } \\
\text { colorful bottles } \\
\text { from } 1 \text { to } 10 \\
\text { correctly }\end{array}$ & $\begin{array}{l}\text { Observation } \\
\text { sheet } 1\end{array}$ \\
\hline $\begin{array}{l}\text { Pointing } \\
\text { number } 1-10\end{array}$ & $\begin{array}{l}\text { Children are } \\
\text { able to pint } \\
\text { number } 1-10 \\
\text { correctly. }\end{array}$ & $\begin{array}{l}\text { Observation } \\
\text { sheet } 2\end{array}$ \\
\hline
\end{tabular}

Table 2. Scoring Rubric for number sense on group $A$

\begin{tabular}{|c|c|c|c|}
\hline Indicators & Criteria & Score & Description \\
\hline \multirow[t]{3}{*}{$\begin{array}{l}\text { Counting } \\
1-10\end{array}$} & $\begin{array}{l}\text { Always } \\
\text { right }\end{array}$ & 2 & $\begin{array}{l}\text { The students } \\
\text { were always } \\
\text { right on } \\
\text { counting } 1 \text { - } \\
10 \text {. }\end{array}$ \\
\hline & $\begin{array}{l}\text { Sometimes } \\
\text { right }\end{array}$ & 1 & $\begin{array}{l}\text { The students } \\
\text { were } \\
\text { sometimes } \\
\text { right on } \\
\text { counting } 1 \text { - } \\
10 \text {. }\end{array}$ \\
\hline & $\begin{array}{l}\text { Never } \\
\text { right }\end{array}$ & $\mathbf{0}$ & $\begin{array}{l}\text { The students } \\
\text { were never } \\
\text { right on } \\
\text { counting } 1- \\
10\end{array}$ \\
\hline \multirow[t]{3}{*}{$\begin{array}{l}\text { Pointing } \\
\text { number } 1- \\
10\end{array}$} & $\begin{array}{l}\text { Always } \\
\text { right }\end{array}$ & 2 & $\begin{array}{l}\text { The students } \\
\text { are always } \\
\text { right in } \\
\text { pointing } \\
\text { certain } \\
\text { number. For } \\
\text { example: } \\
\text { students can } \\
\text { point number } \\
6 \text { correctly. }\end{array}$ \\
\hline & $\begin{array}{l}\text { Sometimes } \\
\text { right }\end{array}$ & 1 & $\begin{array}{l}\text { The students } \\
\text { can point at } \\
\text { correct } \\
\text { number, but } \\
\text { sometimes } \\
\text { forget. }\end{array}$ \\
\hline & $\begin{array}{l}\text { Never } \\
\text { right }\end{array}$ & 0 & $\begin{array}{l}\text { The students } \\
\text { are never } \\
\text { right in } \\
\text { pointing } \\
\text { number. }\end{array}$ \\
\hline
\end{tabular}

The test was in the form of students' worksheet consisting three indicators, namely pointing number by circling the correct number, and connecting or matching number with things, and finding out whether the number of things is more, less, or equal.

The data collected from observation and test were analyzed using descriptive quantitative technique. The analysis was used to determine improvement of students' learning outcome as the result of the treatment. Based on the preliminary tryout, the data in the main tryout and operational tryout were analyzed and 
expressed in percentage. The calculation of the analysis data resulted in achievement percentage interpreted by sentences. The formula was presented as follows.

$\mathrm{X} \%=\frac{\text { all scores obtained in group }}{\text { number of group } \times \text { maksimum score }} \times 100 \%$

The result from the formula was then interpreted into four stages as follows.

1. Excellent, if the total score is between $76 \%-100 \%$.

2. Good, if the total score is between $51 \%$ $-75 \%$.

3. Fair, if the total score is between $26 \%$ $50 \%$.

4. Poor, if the total score is between $0 \%$ $25 \%$.

\section{RESULTS AND DISCUSSION}

\section{Bowling Number}

Bowling number is a game adapted from bowling game and has been modified by the researcher. In employing bowling game, the first step to do was preparing the tools and materials. Some medium balls and colourful bottles with written number on it were prepared. To do the game, first, the students were asked to line up $( \pm 3-4$ children) and all of them were given a ball. Second, they were asked to roll their ball toward the target, colourful bottles set in a V-shape. Third, they gave the knockeddown bottles to the teacher.

The teacher asked them the number of bottles they have knocked down. From this game, it can be inferred that the motivation of students to learn, particularly on recognizing numbers, increased. It can be seen from the result of the observation sheet analysed in a percentage and the comparison between pretest and posttest with two treatments. The analysis and comparison between pretest dan posttest are presented as follows.

Table 3. Analysis and Comparison of Pretest dan Posttest on Bowling number games

\begin{tabular}{|c|c|c|c|c|c|c|c|}
\hline \multirow{3}{*}{ No } & \multirow{3}{*}{ Indicators } & \multicolumn{6}{|c|}{ Percentage } \\
\hline & & \multicolumn{2}{|c|}{ Pretest } & \multirow{2}{*}{$\begin{array}{c}\text { Treatment } 1 \\
\text { (Posttest 1) }\end{array}$} & \multicolumn{3}{|c|}{ Treatment 2 (Posttest 2) } \\
\hline & & $\begin{array}{c}\text { Observation } \\
\text { sheet }\end{array}$ & $\begin{array}{c}\text { Works } \\
\text { heet }\end{array}$ & & $\begin{array}{c}\text { Works } \\
\text { heet }\end{array}$ & $\begin{array}{c}\text { Observation } \\
\text { sheet }\end{array}$ & $\begin{array}{c}\text { Works } \\
\text { heet }\end{array}$ \\
\hline 1. & $\begin{array}{l}\text { Pointing } \\
\text { number } 1 \text { - } 10\end{array}$ & $47,67 \%$ & $54,33 \%$ & $66,50 \%$ & $71,16 \%$ & $84,08 \%$ & $87,67 \%$ \\
\hline 2. & $\begin{array}{l}\text { Connecting or } \\
\text { matching the } \\
\text { things with } \\
\text { their number } 1 \\
-10\end{array}$ & $49,00 \%$ & $59,00 \%$ & $68,08 \%$ & $74,50 \%$ & $83,50 \%$ & $88,66 \%$ \\
\hline
\end{tabular}

From the table above, the implementation of bowling number game can significantly increase the 4-5 -yearold-students' competence in identifying number. It can be seen from the comparison between pretest and post test on first and second indicator demonstrating the improvement. The last result $\left(2^{\text {nd }}\right.$ treatment) is categorized as excellent as the score obtained $>76 \%$ on each indicator and on each instrument.

\section{Matching it}

In employing this game, the researcher adapted and modified the running game. It is a simple game but most 
of children like it. They need to run back and forth to take certain things like flags or balls. For this study, the game was modified into flags with number on it and the students need to go back and forth to take balls based on the number on the flags. The result shows that the students moved actively, their number sense increased, even their psychomotor developed since their muscles were used here. They were also enthusiast in joining the games. Those big enthusiasm resulted in the improvement of their number sense significantly. It can be seen from the comparison of the percentage of pretest and posttest on both treatments. The comparison can be seen as follows.

Table 4. Comparison Pretest and Posttest on Matching It games

\begin{tabular}{|l|l|c|c|c|c|c|c|}
\hline \multirow{2}{*}{ No } & \multirow{2}{*}{ Indicators } & \multicolumn{4}{|c|}{ Percentage } \\
\cline { 3 - 7 } & $\begin{array}{c}\text { Pbservation } \\
\text { sheet }\end{array}$ & Worksheet & $\begin{array}{c}\text { Observation } \\
\text { sheet }\end{array}$ & Worksheet & $\begin{array}{c}\text { Observation } \\
\text { sheet }\end{array}$ & Worksheet \\
\cline { 2 - 7 } & $\begin{array}{l}\text { Pointing number } \\
1-10\end{array}$ & $45,50 \%$ & $52,67 \%$ & $60,67 \%$ & $69,50 \%$ & $78,50 \%$ & $82,67 \%$ \\
\hline 2. & $\begin{array}{l}\text { Connecting or } \\
\text { matching the } \\
\text { things with their } \\
\text { number 1-10 }\end{array}$ & $49,00 \%$ & $53,50 \%$ & $62,16 \%$ & $72,00 \%$ & $80,50 \%$ & $84,50 \%$ \\
\hline
\end{tabular}

From the above table, it can be inferred that the implementation of matching it games can improve students' number sense significantly at the year of 4 -5 . It can be inferred that the the result of posttest on each indicator increased, compared to the pretest. The last result $\left(2^{\text {nd }}\right.$ treatment) is categorized as excellent as the score obtained $>76 \%$ on each indicator and on each instrument used.

\section{DISCUSSION}

It cannot be denied that the number sense is one of competences used in daily life. The importance of the competence indicates that number should be introduced since the early childhood. Mathematics is said as crucial in daily life. However, in fact, people think that learning Mathematics is 'depressing' or 'frightening' because it is related to numbers .
Researches employed by some experts (Nilsson et al., 2009) and (Misfeldt \& Zacho, 2016) show suprising results. They state that the motivation of children to learn Mathematics increased recently and gradually as the changing of era and technology. National Council of Teachers of Mathematics (NCTM) (Dunphy et al., 2014) clarifies that Mathematics contents for children includes numbers sense, geometry, measurement, algebra, and data presentation. It cannot be rejected that all of the Mathematics contents are related to children's daily life and can be found easily around them.

One of the Mathematics activity needed to be developed is recognizing number (number sense). It becomes an important thing as their daily life cannot be separated from numbers (Lestari KW, 2011). The ability to recognize numbers becomes one of the competences required and used in daily life. The importance of that competence indicates that number 
should be introduced since the early childhood. Thus, the role of parents at home and the role of teachers at school become important to develop this competence. Parents and teachers need to have certain methods and strategies in introducing number to early childhood as this competence seems easy but actually difficult. This was proven by the result of observation and interview of this study on ten kindergarten schools and teachers in Bantul district stating that early childhood (4-5 years old) still felt difficult to recognize number $1-10$.

This study aimed at improving the students' competence to recognize number through the implementation of outdoor games for kindergarten students at year of 4 - 5. The students' participation and interest on these outdoor games were seen on the improvement of their competence. It means that these outdoor games are effective to be employed in kindergarten, of course with teachers' support.

From the two outdoor games (bowling number and matching it) employed in kindergarten class A (4-5 years old), it can be inferred that the students' number sense increased and even belonged to excellent criteria. The design of the study taking outdoor setting allowed the students to be free in expressing their self and to move freely compared to usual classroom learning they did. They thought that outdoor classroom was more interesting and exciting, so they do not only develop their numerical awareness but also build their confidence and their psychomotor.

The impact of these outdoor games also can be seen on the teachers' perspective in designing classroom activities. The teachers considered outdoor games effective to develop students' awareness of number. They shift their perspective from their old thought that outdoor games are difficult to be done since the tools and materials are limited. The fact is that outdoor games can be employed in a simple way using simple tools and materials found on the surrounding.

\section{CONCLUSION}

The result of the research conducted in a kindergarten group A (4-5 years old) in Bantul district shows that outdoor games are effective to be employed in teaching kindergarten as their effects can improve the students' number sense. When children play games directly through concrete things and learner-centred style, meaningful learning occurred. The students' activities and enthusiasm in playing the games were higher so they felt happy.

The implementation of outdoor games also can shift teachers' perspective on the type of teaching methods they use. Thus, this kind of games becomes an alternative way to introduce number to young learners (early childhood).

\section{ACKNOWLEDGMENT}

My gratitude goes to the headmaster and teachers in TK Aisyiyah Bustanul Athfal Babakan for helping and facilitating the research process. In addition, I thank the Editor team of Obsesi journal for enabling this journal to be ready to publish.

\section{REFERENCES}

Daryati. (2013). Upaya Meningkatkan Kemampuan Mengenal Angka melalui Permainan Tradisional Gamang. PG PAUD UMP.

Dunphy, E., Dooley, T., Shiel, G., Butler, W. D., Corcoran, D., Ryan, M., \& Travers, J. (2014). Mathematics in Early Childhood and Primary Education (3-8 years), (17). 
Fitria, A. (2013). Mengenalkan dan Membelajarkan Matematika Pada Anak Usia Dini. Jurnal Studi Gender Dan Anak, 1(2), 45-55.

Hinkley, T., Brown, H., Carson, V., \& Teychenne, M. (2018). Cross sectional associations of screen time and outdoor play with social skills in preschool children. PLOS ONE, 13(4), 1-16. https://doi.org/10.1371/journal.pone. 0193700

Misfeldt, M., \& Zacho, L. (2016). Supporting primary-level mathematics teachers' collaboration in designing and using technologybased scenarios. Journal of Mathematics Teacher Education, 19(2-3), 227-241. https://doi.org/10.1007/s10857-0159336-5

Nah, K. O., \& Lee, S. M. (2016). Actualizing children's participation in the development of outdoor play areas at an early childhood institution. Action Research, 14(3), 335-351.

https://doi.org/10.1177/14767503156 21610

Nilsson, P., Sollervall, H., \& Milrad, M. (2009). Collaborative design of mathematical activities for learning in an outdoor setting, 1101-1110. Retrieved from http://www.inrp.fr/publications/editio n-electronique/cerme6/wg7-06nilsson.pdf

Pradana, P. H. (2016). Pengaruh Permainan Balok Angka Terhadap Kemampuan Mengenal Lambang Bilangan Pada Anak Usia Dini. Jurnal PAUD Tambusai, 2(2), 1825. 